Science Life

\title{
DEVELOPMENT OF THE ORGAN TRANSPLANT SERVICE IN LATVIA: A REVIEW
}

\author{
Rafails Rozentāls*, Jānis Bicāns*, Sergejs Truškovs*, Jānis Jušinskis*, \\ Viktors Ševeḷovs*, and Anita Nikolajenko** \\ * Latvian Transplantation Centre, Pauls Stradiṇš Clinical University Hospital, Pilsoṇu iela 13, Rīga, LV-1002, LATVIA; \\ rafails.rozentals@stradini.lv \\ ** Institute of Innovative Biomedical Technology, Inčukalna iela 2, Rīga, LV-1014, LATVIA
}

\section{INTRODUCTION}

To put into effect complex high-tech treatment and to cover an increasing number of patients with modern medicine, it is necessary to create and continuously improve the forms of organisation. Over the last few years, medicine has seen many revolutionary changes. The following has been implemented in practice: transplantation of vital organs, robotics, gene therapy, stem cell transplantation, nanotechnology etc. These new methods of treatment, earlier considered impossible, ensure progress in complex tertiary therapy and allow to save lives of thousands of patients.

One of the main conditions for the application of innovative methods is involvement and formation of an association of experts from various fields of medicine. Integration into a single centre is the most reasonable way to optimise specialised medical care with the most cost-effective expenditure of resources (Hammer and Champy (2001).

Organ transplantation was the first field of medicine that was integrated in such unified centres. This enables to provide combined complex clinical care with further follow-up of the operated patients, while simultaneously taking into account and dealing with the economic aspects of transplantation therapy. Costs of transplantation are continuously increasing and there is a need to turn the professional medical orientation to compensation of such costs during treatment. The most urgent issue is still the need for continuous personnel training and involvement of new young professionals in the work (Braunwald, 2006).

The forms used to establish the centres and to function as associations, really differ: from simple clinical departments of hospitals to independent health-care facilities with their own budget and administration (Howard and Kaplan, 2008).

\section{COMING INTO BEING OF A TRANSPLANT SERVICE IN LATVIA}

Practical transplantation worldwide began with a kidney transplant, which is the basis of clinical organ transplantation. In turn, kidney transplant developed based on haemo- or peritoneal dialysis, without which it is impossible to prepare patients for transplantation and to provide an adequate postoperative period. Therefore, there were always departments in the centres of the early days of transplantation that were engaged in kidney transplantation and haemodialysis. Such a practice existed in many countries (Samuels and Blagg, 1975). In the mid 1970s of the last century, a progressive form of specialised health care was developed and implemented in Latvia - educational, scientific and medical associations. The main basis of the centre was the multi-field clinical hospital - Pauls Stradiņ̌ Hospital. The centre was comprised of specialized departments of the clinical hospital, the Research Department of the higher educational institution and the Department of the Riga Medical Institute. The structure of the Transplant Centre in 1973-1991 is shown in Figure 1 (Канеп и др., 1978). The first kidney transplantation was made in 1973 (Fig. 2).

The Tissue Typing Laboratory required for transplant treatment was organised, and it has been operating up to now at the National Blood Donor Centre.

Our centre was among the best in the former USSR, regarding the level of the medical care provided and the research, which confirmed the rectitude of the organisational structural formations.

\section{MODERN ORGANISATION OF THE TRANSPLANT SERVICE}

Political and social changes in the country that took place in 1991 affected the structure and function of the centre. Latvia introduced the specialty of transplant surgeon. In 1996, the Balttransplant coordination office was established. Its staff is responsible for the coordination, recovery and allocation of donor organs, exchange of organs, and development of a waiting list for transplantation and promotion of transplanting among the Baltic States.

The laboratory enabling to provide quality control and safety of transplantation treatment, and to manage the necessary testing of donors and recipients was established and certified at the centre. The increasing number of patients 


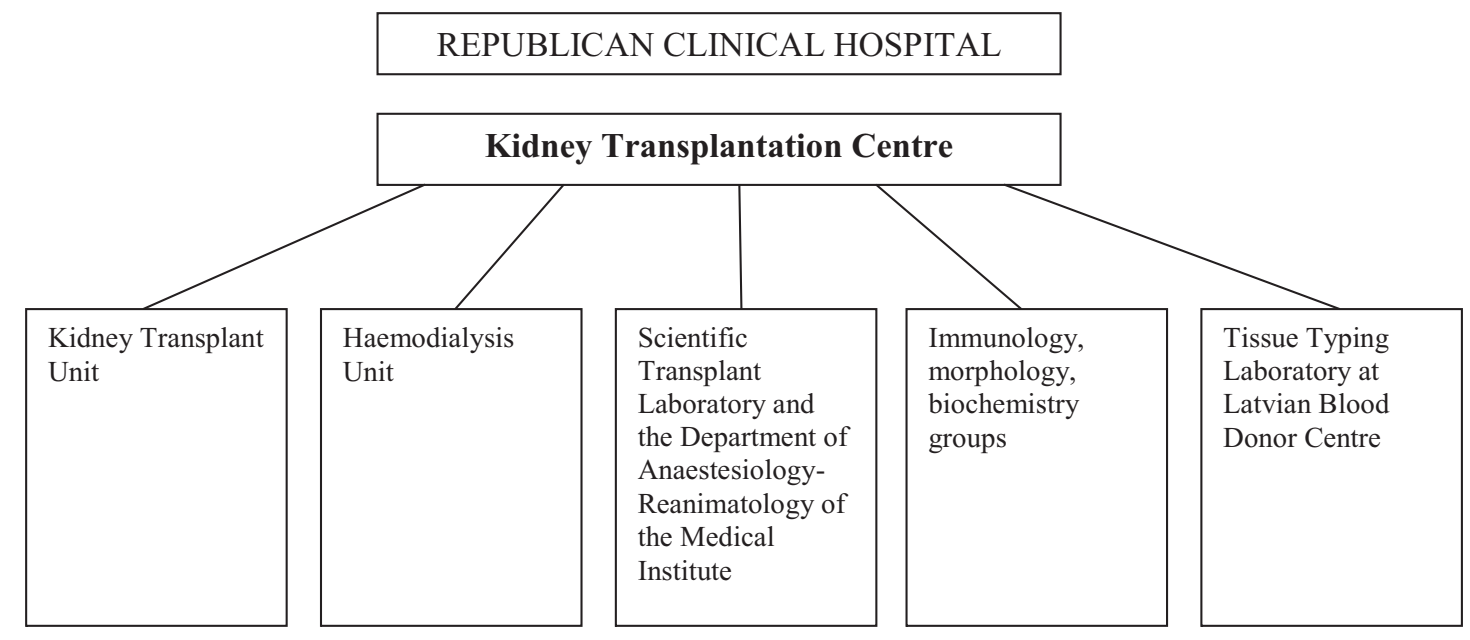

Fig. 1. Former structure of the Kidney Transplant Centre in Latvia.

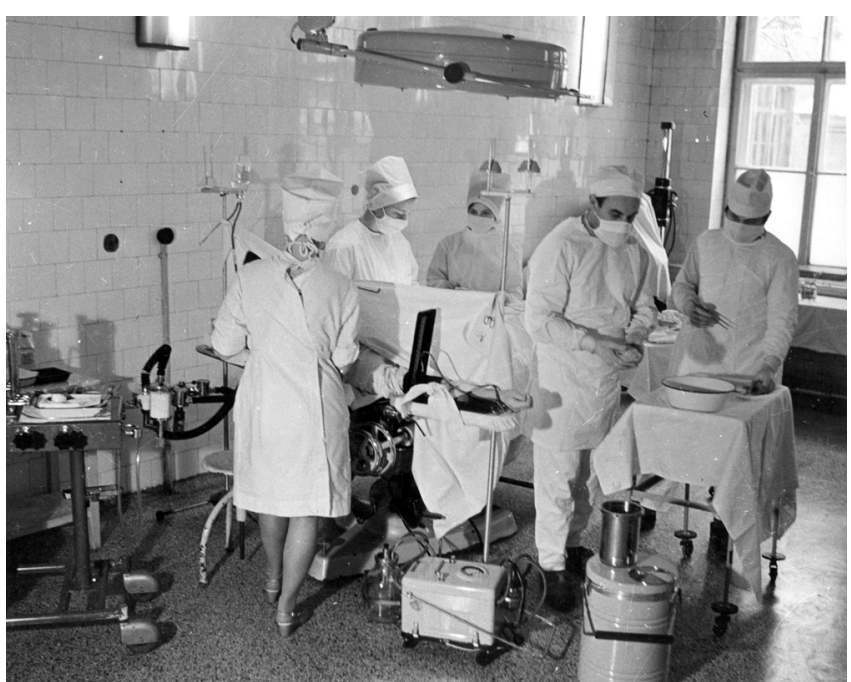

Fig. 2. First kidney transplantation in Latvia on 15 April 1973.

with a transplanted kidney led to the formation of an outpatient service. We have maintained a scientific laboratory at the Rịga Stradiňš University. The structure of the modern Transplantation Centre is given in Figure 4. The centre annually provides 70-75 kidney transplants, which complies with the average European data (Fig. 5). Moreover, if necessary, our personnel successfully recover also hearts and liver for transplantation and are able to take part in these operations.

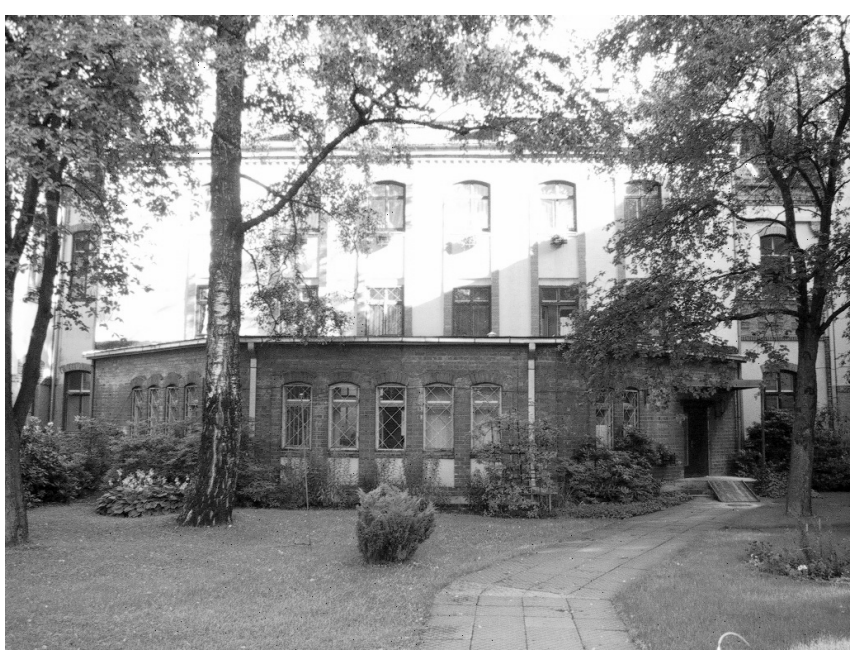

Fig. 3. Latvian Transplantation Centre at Pauls Stradiņ̌̌ Clinical University Hospital.

\section{FURTHER DEVELOPMENT CONCEPT}

The personnel of the currently operating centre provide progress in the field of kidney transplant (quantity and quality of kidney transplantations, training in transplantation and nephrology, safety and quality control, immunosuppressive therapy, etc.).

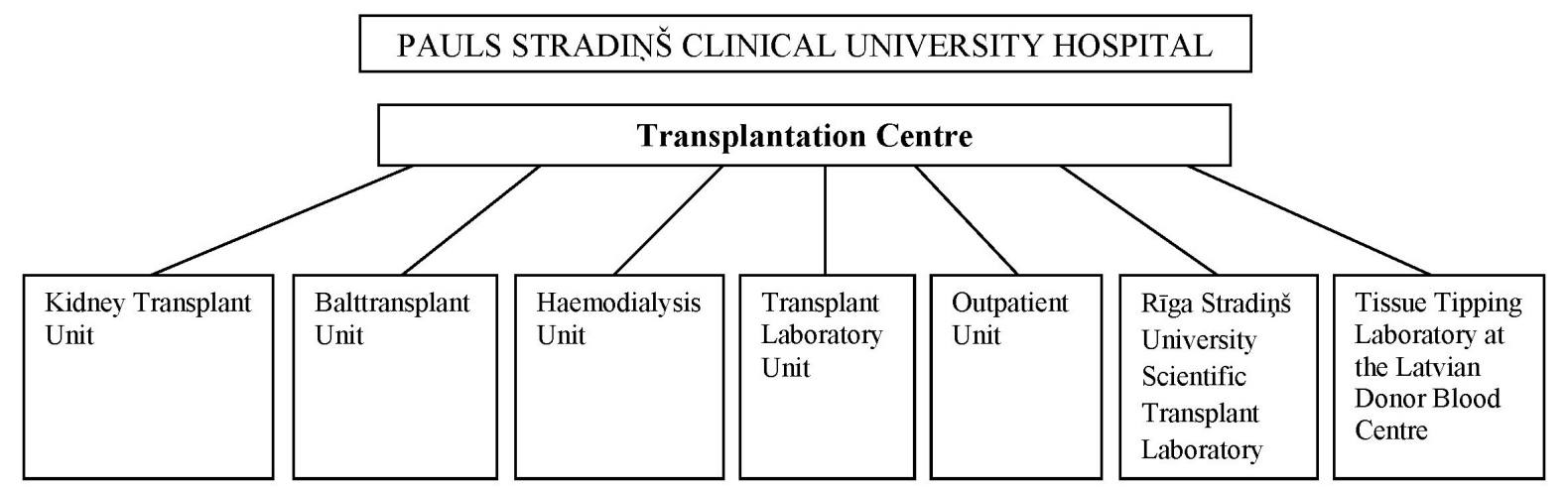

Fig 4. Present structure of the Transplant Centre in Latvia 


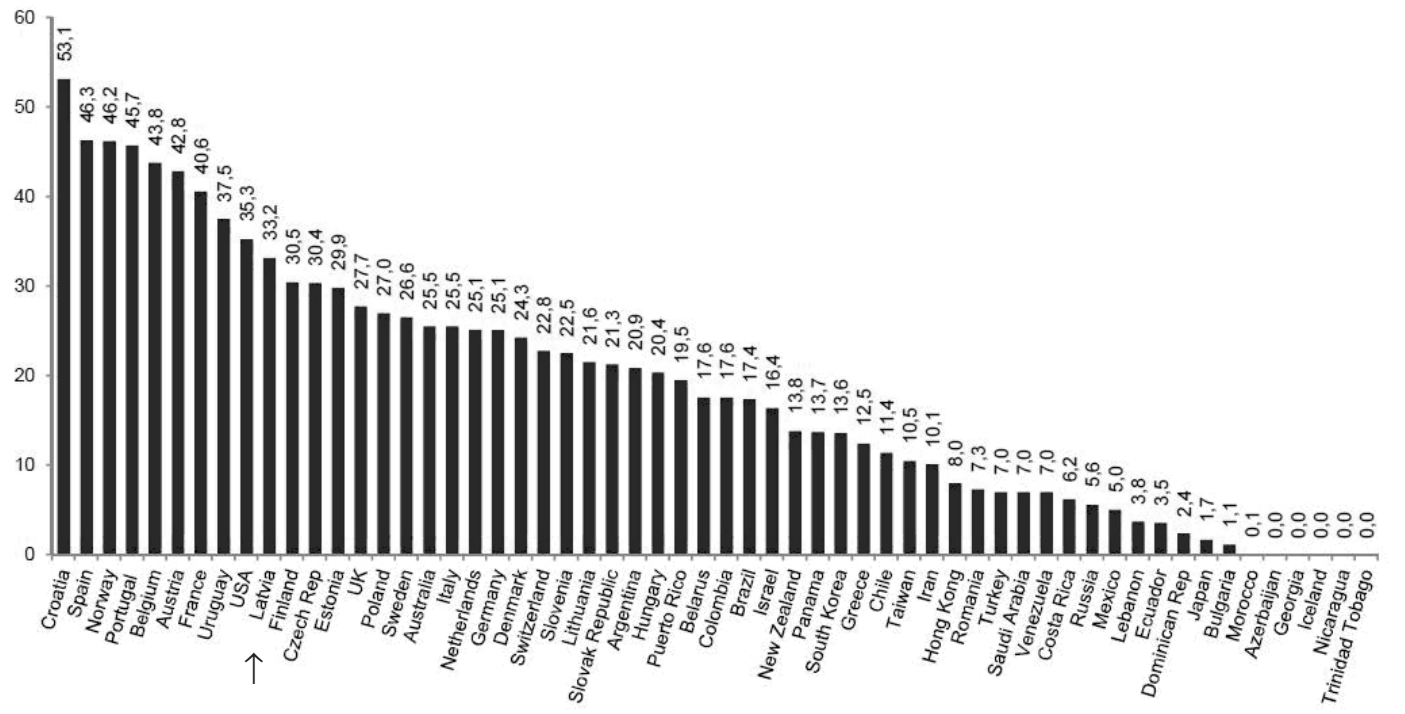

Fig. 5. Deceased kidney transplant, 2011.
Many years of experience gained is the foundation for further progress in the field of transplantation. However, its implementation requires significant changes. Structure of the existing transplant centre is out of date and requires transformation in accordance with the needs and opportunities of the time.

To solve the problems of transplantation of other vital organs - heart, lungs, liver, pancreas - there is a need to renovate the transplant centre. It should remain within the structure of the Clinical University Hospital, because transplantation requires not only experts, but modern operating rooms, highly skilled anaesthesia personnel and a radiological department, blood service and specialists in the field of infectology, etc.

Emerging trends suggest a deviation from transplantation of only one transplant organ (kidney) to the multi-organ transplantation of abdominal cavity organs. That is why the centre must contain a department of surgical transplantation of abdominal cavity organs (kidneys, liver, pancreas), the Balttransplant coordination office and laboratory transplantation service to provide quality control and security (general clinical and biochemical analysis of blood and urine, determination of antibodies to HIV, hepatitis C and B, syphilis, HCMV, the level of immunosuppressants in blood), and also conduct tissue typing. The centre should still maintain a research laboratory (Fig. 6).

The implementation of our proposals, which involve fundamental improvement of activities in the field of the topical branch of innovative medicine will require a number of additional strategic measures:

- construction of new buildings in the Pauls Stradiņš hospital;

- establishment of an academic centre of transplantation medicine, where the hospital and higher educational institution are subordinated to a single administration (Levin et al., 2008). The initial step is to amalgamate the hospital with the Rīga Stradiňš University;

- increased development of travel for transplantation in the area of organ transplantation (Chin and Cambell, 2012).

Carrying out of the above structural and functional changes will:

- improve and expand the quality of specialised transplant care in Latvia;

- ensure the economic efficiency. Organ transplantation allows patients to return to their work. This means an increase

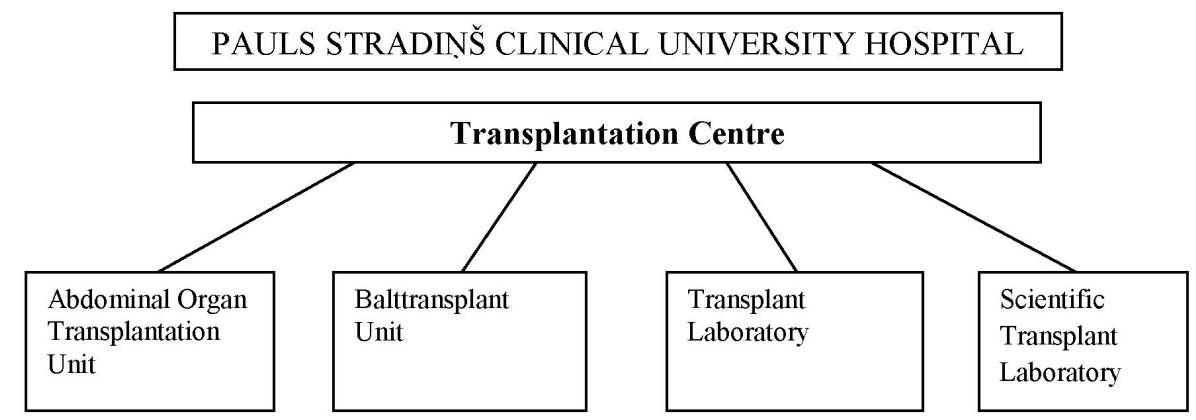

Fig. 6. Project of reorganisation of the Transplant Centre in Latvia (note: heart and lung transplantation is the prerogative of the thoracic and cardiac surgeons and should be made in the respective centres). 
of the gross domestic product of the state. Kidney transplantation is significantly cheaper compared to haemodialysis or peritoneal dialysis; liver transplantation will prolong the life of a part of patients. Travel for transplantation will enable to use all organs suitable for transplantation in our country in order to avoid associated losses, and also to provide additional income to the hospital and its personnel;

- strengthen the nephrology service of the hospital by integrating the departments of haemodialysis and the outpatient service;

- provide training of students, trainees and researchers on issues related to transplantation;

- significantly increase the participation of personnel of the centre in clinical studies of various problems of organ transplantation.

We understand how difficult it is to solve these problems in the present day state of medicine. However, we believe that our long-term positive work experience allows to speak of the need for strategic planning in public health. Only in this way is it possible to keep up with the development of medicine in Europe.

\section{REFERENCES}

Braunwald, E. (2006). Departments, divisions, and centres in the evolution of medical schools. Amer. J. Med., 119, 457-462.

Chin, J., Ńampbell, A. (2012). Transplant tourism or international transplant medicine? A case for making the distinction. Amer. J. Transplant., 12, 1700-1707.

Hammer, M., Champy, J. (2001). Reengineering the Corporation. A Manifesto for Bussiness Revolution. New York: Harper business. 75 pp.

Howard, R., Kaplan, B. (2008). The time is now: Formation of the true transplant centres. Amer. J. Transplant., 8, 2225-2229.

Levin, S., Saxton, J., John, M. (2008). Developing integrated clinical programs. Its what academic health centres should do better than anyone. So why don't they? Acad. Med., 83, 59-65.

Samuels, S., Blagg, C. (1975). Twelve years experience at the Norwest kidney centre. Dialysis Transplant, 4, 60-70.

Канеп В., Андреев Г., Розенталь Р., Ярмолинский И., Даугулис Э. (1978). Опыт организации и работы Латвийского центра по трансплантации почек [Organisational and work experience of the Latvian Kidney Transplant Centre]. В кн: Программныци гемодиализ и трансплантация почки. Рига, с. 5-15.

\section{ORGĀNU TRANSPLANTĀCIJAS PIEREDZE LATVIJĀ}

Jau pagājuši 40 gadi kopš pirmās nieres transplantācijas Latvijā, un pa šo laiku šajā jomā ir uzkrāta liela pieredze. Eiropā Latvija ienem stabilu pozīciju nieru transplantācijā. Tomēr turpmāka transplantācijas attīstība Latvijā prasa transplantācijas centra restrukturizāciju. 